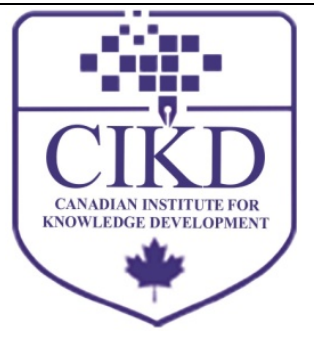

\title{
The Impact of University Social Responsibility towards Producing Good Citizenship: Evidence from Malaysia
}

\author{
Roziana Shaari $^{\text {* }}$, Azlineer Sarip ${ }^{1}$, Azizah Rajab ${ }^{2}$, Wan Zarina Wan Zakaria ${ }^{2}$ \\ ${ }^{1}$ Faculty of Management, Universiti Teknologi Malaysia, 81310 UTM Johor Bahru, Johor \\ ${ }^{2}$ Language Academy, Universiti Teknologi Malaysia, 81310 UTM Johor Bahru, Johor
}

\begin{abstract}
Keywords:

University Social Responsibility, Good Citizenship, Community Impact, Social Impact

\section{Received}

16 May 2018

Received in revised form

22 September 2018

Accepted

30 September 2018

Correspondence:

rozianas@management.utm.my

This paper provides empirical evidence on university social responsibility efforts and how it impacted community. The objectives are to investigate the role UTM plays within and outside UTM boundary in providing facilities and services to the community; and to explain how the facilities and services provided by UTM impacted the community. The study employed secondary data, surveys and focus group discussion to collect data on social impacts. The findings explain on how a university impacted on producing good citizenship through providing facilities and services to their community.

The role of the university in the community has been a very persistent topic being discussed by scholars. Universities are known as having a direct influence on the quality of life in the community due to their educational, research and social actions. The social responsibility of a university is to strengthen civic responsibility and active citizenship through volunteerism, ethical approach and the development of a sense of civic responsibility, where students and academic staff are encouraged to be involved in the local community through social services programs such as promoting the commitment from local and global sustainable development in
\end{abstract}


the preservation of the environment. These could advocate a corporate identity of an institution or a university and can function as a powerful tool of competitive advantage.

\section{Literature Review}

Numerous studies have proven that firm which supports socially responsible activities may generate towards positive association with a firm's performance (Mustafa, Othman, \& Perumal, 2012). Therefore, companies are likely to gain competitive advantage by involving in good corporate citizenship (Lockwood, 2004). Intangible assets are said to become increasingly important in an organization and should be considered by all business which includes the reputation, brand equity as well as company values and also includes the human and intellectual capital. Similarly, universities as a distinctive kind of organization should develop social responsibility initiatives just like other organization as an approach to meet their stakeholder satisfaction (Vasilescu, Barna, Epure, \& Baicu, 2010).

The understanding of University Social Responsibility (USR) is considered initial as it differs in focus, extent and action of universities, for instance between community engagement or community service as shown in Table 1.

Table 1

USR Framework

\begin{tabular}{ll}
\hline University & USR Framework (focus) \\
\hline University of Groningen (Netherlands) & $\begin{array}{l}\text { research-centred } \\
\text { approach (collaboration between the university and the city) - Knowledge Valorisation } \\
\text { community outreach and involve students in such activities. }\end{array}$ \\
Jagiellonian University, Krakow, Poland) & $\begin{array}{l}\text { social inclusion e.g. supporting social events } \\
\text { Teesside University }\end{array}$ \\
Monash University & $\begin{array}{l}\text { community outreach, building and development } \\
\text { Universiti Kebangsaan Malaysia }\end{array}$ \\
Universitat Politècnica de València (Spain) & Wellbeing of students \\
\hline
\end{tabular}

Universiti Teknologi Malaysia (UTM) is a leading innovation-driven entrepreneurial research university in engineering science and technology. It is located both in Kuala Lumpur, the capital city of Malaysia and Johor Bahru, the southern city in Iskandar Malaysia, which is a vibrant economic corridor in the south of Peninsular Malaysia. UTM has about 25,000 students and 3,600 academic students as resources to support for university's mission and vision. USR efforts in UTM nowadays could be considered as a critical success factor through concentrated effort and strong team spirit by the university community including its staff and students. Therefore, higher education administrations should direct more emphasis because they started to view the faculty development as a community service and outreach (Akdere \& Egan, 2005). This is affirmed by Eyler (2002) that in enhancing the engagement among the university community, it needs diverse actions such as developing in service-learning courses and educations for citizenship as well as widening the faculty scholarship and service through encouraging community partnership. It is crucial for UTM to report their USR activities as it may improve their social responsibility towards their neighborhood. By doing this, it enables UTM to sustain and remain competitive as established research university. The University of Edinburgh for instance, promotes their USR through university websites to demonstrate how they contribute to the community. By promoting USR not only it demonstrates university's commitment to social responsibility practices, but gains public image and improve reputation 
(Chen, Nasongkhla, \& Donaldson, 2015); for example, attracting additional sources of funding; enhanced institutional identity; increased research productivity and opportunities through new partnerships; and involvement of staff and students in the discovery and application process, thereby fostering the development of highly-valued workforce skills and practical knowledge (Cuthill, 2008). Unfortunately, UTM was claimed to have poor in considering publishing their USR activities as compared to other larger universities (Ahmad, 2012). Thus, our study contributes to provide empirical evidences on how UTM impacted community by providing various facilities and services. In particular, the objectives of the study are two fold namely (1) to investigate the role UTM plays within and outside UTM boundary in providing facilities and services to the community; and (2) to explain how the facilities and services provided by UTM impacted the community.

USR ranking will drive a university forward and promote a positive image through social responsibility efforts. On the other hand, the active role played by the university is not only producing good citizenship, in fact, renewing civic responsibility among its members particularly students and staff who involve as volunteer. Thus, this is also considered as a decisive mission (Sawasdikosol, 2009). By volunteering engage at a community or social level, wellbeing and resilience level of the volunteers can boost up. The linkage between volunteering and "leading the good life" was discussed by Wilson and Musick (2000) who studied on the effects of volunteering support. Volunteering is not just fostering empathy feeling but interpersonal trust, toleration for others, and respect for the common good. The belief level in volunteers enables them to make a difference and enhance their personal efficacy. This process is not a natural instead it must be facilitated, and a university role is demanded to produce good citizenship for the future (P21 Partnership for 21st Century Learning, July 2014). In conjunction with this, for a university, some of the intended contribution such as providing services to community engagement and outreach, enhancement of national heritage in arts, religion and culture, and ensuring the well-being of the community are crucial (Asia-Europe Foundation's ASEM Education Hub (AEH) and the University of Innsbruck, June 2011).

The scope of this research is focused on social impacts among communities or UTM neighbors. As supported by Jamillah (2012), university has important roles in not only preserving the environment but more importantly in increasing public responsiveness or awareness. Thus, all necessary steps must be carried out to improve the quality of life for all its employees and their families, students, faculties, the local and international communities as well as society at large. Research on social impact failed to reach common understanding or solid definition on what constitutes to the impact (CONCERTO, 2010). This is due to the fact that the definition relies heavily on the specific context and thus the various changes in the social environment and social well-being of a community contribute to the problem (Erickson, 2010). Table 2 presents some of the definition or measure on social impact.

Table 2

Social Impact

$\begin{array}{llll}\text { - Community Centres South Australian (2013) } & \text { Di Nucci and Spitzbart (2010) } & \text { Vanclay (2002) } \\ \text { - Participation, generic skills, personal development } & \text { - Degree of satisfaction } & \text { - People's way of life } \\ \text { Extent of volunteerism, use and development of skills } & \text { - Level of participation } & \text { - Their culture } & \text { - Their community }\end{array}$


In this research, we propose the social impacts to be measured based on Kurt Lewin's paradigm of learning (Schein, 1995). Learning is change, knowledge and also behavior. The changes are directed more towards reinforcement than to alteration of patterns of knowledge and behavior. More specifically, the impacts are measured based on Kirkpatrick's model of evaluation: reaction, learning, behavior and results. The community responses to using facilities/services or attending programs provided by the studied units are valued according to the suitability of the concept. How we adapt the concept into this study has also been discussed in the methodology. According to Kirkpatrick and Kirkpatrick (2006), there are 4 levels evaluation or measures. The first level is reaction - a measure of satisfaction; second is learning - a measure of learning (the resulting increase in knowledge or capability); third level is behavior - a measure of behavioral change (extent of behavior and capability improvement and implementation/application; and results level- a measure of results (the effects on the institutional environment resulting from the fellows' performance). The responses obtained through surveys and focus group discussion (FGD), can be mapped according to the 4 levels. This is a suitable approach to measure impact since research on service quality for instance, were also to measure respondents' reaction or perception on specific services or facilities (Berry, Parasuraman, \& Zeithaml, 1994). The questions asked in service quality are consistent to reaction, behavior and results; i.e., 'the company employees give me prompt service'; I would positively recommend the ...... to other people'; 'I am interested in trying ...from another company' (Hellier, Geursen, Carr, \& Rickard, 2003).

\section{Methodology}

This study employs an explanatory research which uses several ways in explaining the objectives. Specifically, the sequential explanatory strategy was used to explain and interpret the results. The focus of the impact was emphasized on sports and leisure, health care, community engagement/voluntary works, capacity building and social/spiritual care. The providers of services/facilities included the Sports centre, Office of Asset and Development, Health centre, Institute of Bio-product (IBD), Centre for Community and Industry Network (CCIN), and Islamic centre. The first phase involved data gathering on archival record or report from 2008 until 2015. However, some of the data were incomplete due to unavailable record. The content analysis method was used for the first phase and data were coded according to their uniqueness as 'facilities' and 'services' entail distinctive characteristics according to various units or providers. The second phase involved surveys and interviews (through focus group discussion) to explore how UTM facilities and services, within and outside UTM boundary have impacted the users of facilities and the participants of program/services. For instance, the engagement of the community in IBD programs was measured according to their reaction and application, e.g., how they benefited or applied knowledge/skill gained from participating in wellness program conducted by IBD (see Table 2). Enumerators were appointed to assist in data collection for surveys. Some of the questionnaires were collected during event, carnivals, programs, the enumerators explained and made a brief to the questions and rateed the answers based on respondent's feedback. Data from surveys were analyzed by Statistics for Social Science (SPSS) version 16.0. Descriptive statistics such as mean, frequency and percentage were used to explain the level of reactions and perceptions. The 
findings of FGD were to support and explain the impact levels. As mentioned earlier, based on the assessment by Kirkpatricks and Kirkpatricks (2006), we adapted the model according to the research suitability and categorized the data into themes (Table 3).

Table 3

\begin{tabular}{llll} 
Community Impact & & & \\
\hline Reaction Level (1) & Learning Level (2) & Behavior Level (3) & Outcomes/Results Level (4) \\
\hline $\begin{array}{l}\text { Satisfaction in using facilities } \\
\text { Satisfaction in receiving } \\
\text { services/ attending program }\end{array}$ & $\begin{array}{l}\text { Community capacity or } \\
\text { capability gained from } \\
\text { attending program }\end{array}$ & $\begin{array}{l}\text { Behavioral changes } \\
\text { Contribution to others based on } \\
\text { what they have learned }\end{array}$ & $\begin{array}{l}\text { Value to community } \\
\text { Improvement to quality of life } \\
\text { Greater life satisfaction } \\
\text { Higher community morale }\end{array}$ \\
(facilities and services) & (Services only) & (facilities and services) & (facilities and services) \\
\hline
\end{tabular}

\section{Findings and Discussion}

\section{UTM Role in Social Responsibility}

The findings on UTM in USR through providing its facilities and services were depicted in Table 1. The massive number of users for sports and leisure indicated the impact. For example, the usage of sports facilities in 2014 illustrated more than 700,000 people/community volunteer time for sport. Whether it is for friendships, games or competition, fitness or pure love of the game, sport is important for UTM's community. Besides, it makes us healthier community, both physically and mentally, sport and leisure also helps to build community confidence and self-esteem and reduce social problem (Australian Sports Commission, 2015). This has brought the idea of interconnection between various forms of capacity building in order to achieve healthy and sustainable development. Among the indicators for sustainable development is protecting natural resources and enhancing the environment (Allin, 2007). 'Pursuing environmental excellence' is also considered as a part of a university social responsibility (Ahmad, 2012). In specific, UTM through its ecotourism program offers various leisure and recreational activities for members of the community. This includes recreational forest, deer park, lake, tropical garden, bird watching station, orchard, and the observatory. The archival data shown in Table 4 reported that these facilities have received visitors from various groups, including local communities, i.e., schools and government agencies. As a result, the natural resources within UTM have enabled the university to offer various outdoor activities for the community, such as camping, jungle trekking, horse riding and kayaking within the university area.

Table 4

UTM'S USR

\begin{tabular}{llcc}
\hline Facilities/Services & & Facts & Year \\
\hline \multirow{3}{*}{ Sports } & Stadium users: & 52,200 & 2014 \\
& Swimming complex users: & 7,731 & 2015 \\
Leisure & Sports complex and others & 662,580 & $2009-2013$ \\
Health care & Visitors & 18,039 & \\
& Visitors & 24,480 & $2008-2014$ \\
Voluntary program & Volunteering hours: & 23,188 & $2009-2011$ \\
& Volunteers: & 5,096 & $2010-2014$ \\
Capacity building & Volunteering projects: & 111 & 17 \\
Social and Spiritual & Programs & 67 & \\
\hline
\end{tabular}


It can be said that the main role played by the UTM as neighbor to the surrounding community is to build and strengthen the knowledge, skills, competencies and the abilities of the communities either through the organization of both its academic or non-academic activities (e.g. student volunteering activities and community-based training programs). For example, UTM, through Islamic Centre has played an invaluable role in disseminating Islamic knowledge to the Muslim community. From 2010 to 2014, more than 60 programs have been conducted by the center.

Another aspect of good citizenship displayed by UTM is through the Centre for Community and Industry Network (CCIN). This centre, which focuses on university-community engagement has promoted voluntarism among its internal community, i.e., staff and students through outreach programs, community-based participatory research. About 5000 staff and students were involved in volunteering projects and spent about more than 20,000 hours. According to Serap and Eker (2007) such effort not only benefits the community but also contributes to enhance corporate image and reputation. The data also suggest the university impact towards social benefits (Community Centres South Australian, 2013) as well as social capital formation (Skinner, Zakus, \& Cowell, 2008).

\section{Perception of UTM's Social Impact}

Respondents were generally asked a few questions through survey on how UTM has impacted community through the provision of facilities and programs. There were 150 participants in this survey (Table 5). The respondents represent public, who majority of them was Malay. Most of them were UTM neighbors, living within $5 \mathrm{~km}$ radius from UTM (44.7\%).

Table 5

Demographic Profile

\begin{tabular}{llcc}
\hline $\begin{array}{l}\text { Gender } \\
(\mathbf{N = 1 5 0 )}\end{array}$ & Male & 65 & 43.3 \\
$\begin{array}{l}\text { Race } \\
(\mathbf{N = 1 5 0 )}\end{array}$ & Female & 85 & 56.7 \\
& Malay & 148 & 98.7 \\
& Chinese & 2 & 1.3 \\
\hline & Less than $5 \mathrm{~km}$ & 67 & 44.7 \\
Distance & $5-10 \mathrm{~km}$ & 20 & 13.3 \\
$\mathbf{N = 1 2 1 )}$ & $11-20 \mathrm{~km}$ & 6 & 4.0 \\
& $21-30 \mathrm{~km}$ & 3 & 2.0 \\
& $31-40 \mathrm{~km}$ & 1 & .7 \\
\hline
\end{tabular}

Findings showed that the majority (91.7\%) of respondents were proud with UTM existence within their neighborhood (Figure 1). They perceived that UTM has positively affected $(90.6 \%)$ community such as income improvement, social status and education level. Indeed, issues such as social problem, traffic, parking, expensive housing rental were minor issues (27.1\%). Although almost half $(46.3 \%)$ of the respondents perceived that UTM has played its roles in contributing to social and economic development of neighborhood area, they wanted UTM to further play its roles $(83.9 \%)$. 


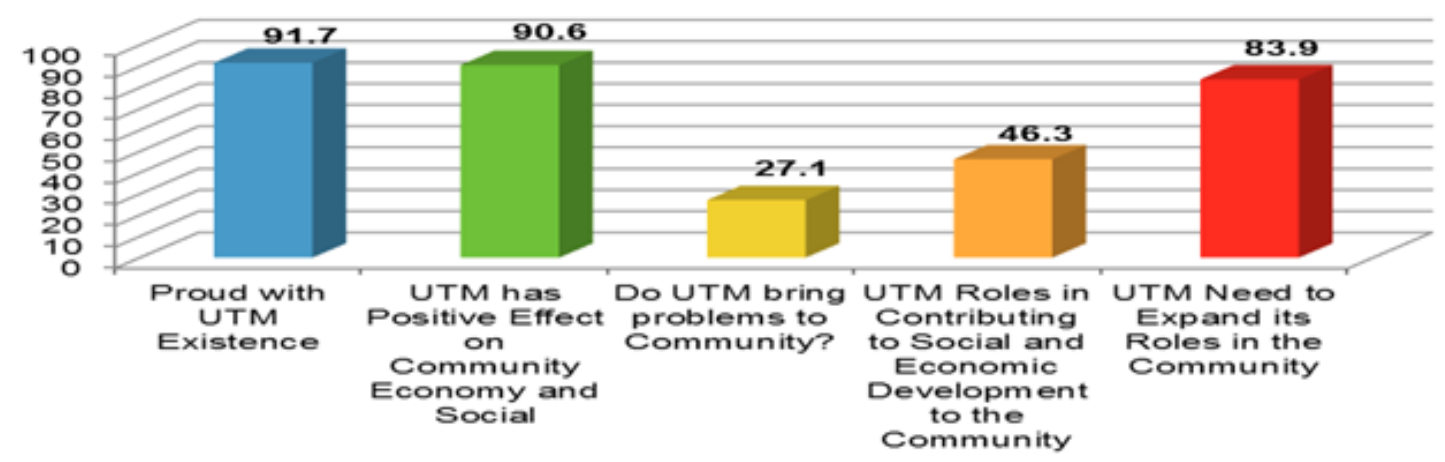

Figure 1. Findings on perception (\%)

The findings from FGD revealed how UTM impact community in nurturing good citizenship. About 20 participants from public were involved to share their experience in using facilities and services. Participants considered UTM facilities valuable and significant to them. They mentioned 'feasible', 'quality', 'full resources', 'good facilities', 'strategic (location)', and 'one-stop-centre' when describing UTM facilities and services. Examples of some responses are shown as follows:

We chose UTM Islamic centre facilities due to its feasibility and quality of the facilities to support our program.

Unlike other institutions like XXX and YYY, the logistic is good and easily accessible by outsiders

We are attracted to do business in UTM because of the strategic location and business network. I would recommend UTM due to its easy access and short distance to our community.

I agree that the location is easy and strategic. Indeed, the facilities could be considered as a one-stop-centre.

According to Allin (2007), the terms well-being, quality of life, happiness, life satisfaction and welfare are often used interchangeably. It is important to note that UTM impact towards societal well-being is not easily identified; as 'changes in societal well-being might intuitively be rather slow to take effect' (Allin, 2007, p. 49).

I do self-reflection from the knowledge gained in the 'tasawur' class to clean my heart. One of the things I did was to forgive others and seek forgiveness for my mistakes.

I would share knowledge that I gained from the programs with my colleagues at work. 


\section{Conclusion}

The findings of this study indicated that UTM has well contributed to 'social capital formation' by engaging with the community - UTM neighbor through its facilities, services and programs conducted. The data from this study has established evidences that UTM facilities and services, as well as programs conducted has benefited all levels of community either in terms of capacity building, community empowerment, promoting a sustainable lifestyle and good citizenship and providing affordable facilities. 'Social impact' is also evident from the data whereby the programs conducted by UTM through its facilities and services has altered the ways in which the community - UTM neighbor - live, work, and play.

\section{Acknowledgment}

This study was supported by the following grant sponsor; Universiti Teknologi Malaysia (UTM) Flagship Funding, Vote No. Q.J130000.2429.02G60.

\section{References}

Ahmad, J. (2012). Can a university act as a corporate social responsibility (CSR) driver? An analysis. Social Responsibility Journal, 8(1), 77-86.

Akdere, M., \& Egan, T. M. (2005). Higher education-community partnerships: An HRD perspective. Paper presented at the International Conference of Academy of Human Resource Development, Bowling Green, OH.

Allin, P. (2007). Measuring societal wellbeing. Economic and Labour Market Review, 1(10), 46-52

Asia-Europe Foundation's ASEM Education Hub (AEH) and the University of Innsbruck (June 2011). Report of the Knowledge Society: Universities and Their Social Responsibilities. Retrieved from https://www.asef.org/images/docs/2nd\%20Asia-Europe\%20Education\%20Workshop_Draft\%20Report.pdf

Australian Sports Commission. (2015). Annual report 2014-2015. Retrieved from: https:/www.ausport.gov.au/_data/assets/pdf_file/0006/611358/CORP_33957_Annual_Report_2014-15_final.pdf

Berry, L. L., Parasuraman, A., \& Zeithaml, V. A. (1994). Improving service quality in America: lessons learned. Academy of Management Executive, 8(2), 32-52.

Cuthill, M. (2008). A quality framework for university engagement in Australia. The International Journal of Public Participation, 2(2), 25-41.

Community Centres South Australian. (2013). A report on economic and social impact study: community and neighbourhood centres sector. Adelaide: Centre for Economic Studies. Retrieved from https://www.communitycentressa.asn.au/documents/item/174

CONCERTO. (2010). Socio-economic impact assessment report. Retrieved from http://concerto.eu/concerto/concerto-sites-aprojects/sites-con-sites/sites-con-sites-search-by-name/sites-ecocity-helsingborg.html

Erickson, M. S. (2010). Investigating community impacts of a university outreach program through lens of service-learning and community engagement (Unpublished doctoral thesis). Retrieved from Digital Repository @ Iowa State University Database.

Eyler, J. (2002). Reflection: linking service and learning-linking students and communities. Journal of Social Issues, 58, 517534.

Hellier, P. K., Geursen, G. M., Carr, R. A., \& Rickard, J. A. (2003). Customer repurchase intention: A general structural equation model. European Journal of Marketing, 37(11), 1762-1800.

Ahmad, J. (2012). Can a university act as a corporate social responsibility (CSR) driver? An analysis. Social Responsibility Journal, 8(1), 77-86.

Kirkpatrick, D. L., \& Kirkpatrick, J. D. (2006). Evaluating training programs. San Francisco: Berrett-Koehler.

Lockwood, N. R. (2004). Corporate social responsibility: HR's leadership role. Indiana University: Society for Human Resource Management. Retrived from http://www. shrm. org. Research/quarterly/1204RQuart_essay. asp.

Mustafa, S. A., Othman, A. R., \& Perumal, S. (2012). Corporate social responsibility and company performance in the Malaysian context. Procedia - Social and Behavioral Sciences, 65(0), 897-905. 
Chen, S. H., Nasongkhla, J., \& Donaldson, J. A. (2015). University social responsibility (USR): Identifying an ethical foundation within higher education institutions. Turkish Online Journal of Educational Technology-TOJET, 14(4), $165-172$.

P21 Partnership For 21st Century Learning (July 2014). The 21st century citizenship guide. Retrieved from http://www.p21.org/storage/documents/Reimagining_Citizenship_for_21st_Century_webversion.pdf

Sawasdikosol, S. (2009). Driving universities' collaboration toward the new era of sustainable social responsibility. Paper presented at the University-Community Engagement Conference 2009, November 23-26, 2009, Penang, Malaysia. San

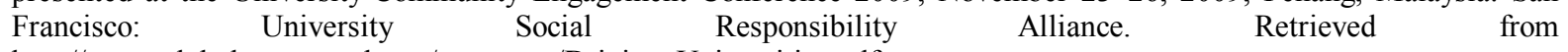
http://www.globalusrnetwork.org/resources/Driving_Universities.pdf

Schein, E. H. (1995). Kurt Lewin in the classroom, in the field, and in change theory: Notes toward a model of managed learning. System Practice, 9(1), 27-47.

Serap Atakan, M. G., \& Eker, T. (2007). Corporate identity of a socially responsible university - a case from the Turkish Higher Education Sector. Journal of Business Ethics, 76, 55-68

Skinner, J., Zakus, D., \& Cowell, J. (2008). Development through sport: Building social capital in disadvantaged communities. Sport Management Review, 11, 253-275.

Vasilescu, R., Barna, C., Epure, M., \& Baicu, C. (2010). Developing university social responsibility: A model for the challenges of the new civil society. Procedia - Social and Behavioral Sciences, 2(2), 4177-4182.

Wilson, J., \& Musick, M. (2000). The effects of volunteering on the volunteer. Law and Contemporary Problems, 62(4), 141168. 